\title{
Differential grazing on natural planktonic populations by the mussel Perna canaliculus
}

\author{
Karl A. Safi ${ }^{1, *}$, B. Hayden ${ }^{2}$ \\ ${ }^{1}$ National Institute of Water and Atmospheric Research (NIWA), PO Box 11115, Hamilton, New Zealand \\ ${ }^{2}$ National Institute of Water and Atmospheric Research Ltd, PO Box 8602, Christchurch, New Zealand
}

\begin{abstract}
Phytoplankton biomass alone cannot predict growth and condition in the mussel Perna canaliculus. This study investigates whether food selection processes, low removal rates of small picophytoplankton-sized particles $(0.2$ to $2 \mu \mathrm{m})$ or additional heterotrophic food sources such as microzooplankton and bacteria may help explain this observation and therefore aid in predicting growth and condition in $P$. canaliculus. Three grazing experiments were run at different times of the year, using naturally varying planktonic assemblages. $P$. canaliculus did not feed efficiently on picophytoplankton or bacterial particles and higher filtration rates were always observed on larger phytoplankton $(>2 \mu \mathrm{m})$. Much of the 0.2 to $2 \mu \mathrm{m}$ size fraction, whether heterotrophic or autotrophic, was not directly utilised for mussel growth. In terms of phytoplankton biomass, grazing and ingestion was often highest on naked flagellated cells. Results indicated that selection of some phytoplankton for ingestion was based on food quality, with both small and large naked flagellated cells with high carbon content often preferred over other morphotypes. $P$. canaliculus also supplemented its diet with heterotrophs, heavily grazing a range of microzooplankton. Grazing overall showed selection for naked flagellated or ciliated microzooplankton with high carbon content. The results indicate that rather than directly accessing picophytoplankton and bacteria, $P$. canaliculus accesses these populations through the food web by grazing upon microzooplankton, mixotrophic algae and, potentially, aggregates. This study adds to our ability to predict mussel condition by identifying key food sources for the growth of $P$. canaliculus.
\end{abstract}

KEY WORDS: Phytoplankton · Size structure $\cdot$ Mussels $\cdot$ Picophytoplankton $\cdot$ Pelorus Sound

\section{INTRODUCTION}

In Pelorus Sound, New Zealand, the growth and condition of the cultured bivalve Perna canaliculus (Gmelin) varies among locations, seasons and years (Meredyth-Young 1983). Although a linkage between mussel condition and phytoplankton biomass, as indicated by chlorophyll a ( $\mathrm{chl}$ a) concentration, has been established (Hickman et al. 1991, Zeldis et al. 2004), the correlation between the two is variable, indicating that other factors besides biomass, such as phytoplankton size and species composition, may also be important in determining mussel condition.

Some species of bivalve can and do use other heterotrophic planktonic sources of food in addition to phytoplankton (Dupuy et al. 1999, Ward \& Shumway 2004) including very small heterotrophic particles such as bacteria (Kreeger \& Newell 1996, 2001, Pile \& Young 1999) and some larger microzooplankton $<200 \mu \mathrm{m}$ in size (Dupuy et al. 1999). There are reports of removal of even larger zooplankton $(>200 \mu \mathrm{m})$ (Lehane \& Davenport 2002, Wong et al. 2003, Zeldis et al. 2004) and in the case of Perna canaliculus ingestion has been observed (Zeldis et al. 2004). Whether heterotrophic food sources have a significant effect on bivalve nutrition will depend on whether the bivalves are capable of capturing and selecting this food type for ingestion and whether these food sources represent a significant food supply in terms of biomass. 
It is now well established that some bivalves preferentially select phytoplankton for ingestion (Shumway 1985a, Dupuy et al. 1999, Ren et al. 2006, Safi et al. 2007) such that size, morphology, particle shape, motility, density, toxicity and nutritional content of the algae are frequently more important than overall biomass (Defossez \& Hawkins 1997, Von Elert \& Stampfl 2000, Viherluoto \& Viitasalo 2001). The feeding mechanism of bivalves is a process of active sorting where nutritious organic prey are ingested while other particles are rejected (Owen 1974). However, before this selection can occur, particles must be removed or captured from the water column. Particles of sufficient size, typically greater than between 1 and $7 \mu \mathrm{m}$ depending on species (Møhlenberg \& Riisgård 1978, Winter 1978, Sobral \& Widdows 2000), are generally easily removed, while smaller particles may be less available as a food source for bivalves.

Perna canaliculus are ciliary and mucus feeders and use cilia on their ctenidia to remove potential food particles from the water. Particles of sufficient size are captured on the frontal surface of the ctenidial filaments and transported by mucociliary processes to the ventral groove. Material in the ventral groove is then transported anteriorly to the labial palps where potential food particles are separated and directed to the mouth. Unwanted particles are bound in mucus and rejected as pseudofaeces (Ward 1996).

Perna canaliculus can efficiently remove and ingest organisms as small as $5 \mu \mathrm{m}$ (James et al. 2001) and more recent evidence indicates that they can also capture and ingest larger particles, including zooplankton (Zeldis et al. 2004). Studies of other bivalves have demonstrated that, as well as food quality, size and shape can be a significant criterion by which particles can be preferentially rejected as pseudofaeces before ingestion (Defossez \& Hawkins 1997), although there is still debate whether size alone is a criterion for rejection (Ward \& Shumway 2004). The degree and efficiency of selection varies among species of bivalves, probably due to differences in feeding behaviour (Hawkins et al. 1996, Ward et al. 1998, Gardner 2002) and in the morphology of the ctenidia and labial palps (Ward et al. 1998, Ward \& Shumway 2004). Recent work has shown that particle selection by suspension-feeding bivalves can also be mediated by interactions between carbohydrates associated with the particle surface and lectins present in mucus covering bivalve feeding organs (Espinosa et al. 2009, 2010) and the content of inorganic particles (Safi et al. 2007)

The distribution of phytoplankton size classes is already recognised as an important effect on diverse aspects of marine systems, including food web structure, water quality and trophic transfer efficiency (Lalli
\& Parsons 1997). It is now well established that many bivalves are unable to efficiently remove cells in the picoplankton size range (Widdows et al. 1979, Dupuy et al. 1999, Tomaru et al. 2002). In 1999, studies conducted in Beatrix Bay, Pelorus Sound, in summer found that picophytoplankton (>0.2 to $2 \mathrm{~mm}$ ) in the top $15 \mathrm{~m}$ of the water column comprised on average $29 \%$ of the phytoplankton biomass but contributed, at times, up to $65 \%$ (Safi \& Gibbs 2003). Consequently the size class structure of phytoplankton in Pelorus Sound may have significant implications for the sustainability of mussel aquaculture in this area. At the same time grazing by the bivalves themselves can alter phytoplankton population structure in areas of high bivalve population density (Cloern 1982, Smaal \& Prins 1993, Cahoon \& Owen 1996) and this could, in part, explain the current population structure in Pelorus Sound.

Phytoplankton within the size range $>0.2$ to $200 \mu \mathrm{m}$ are frequently divided into 3 classes to compare their population structure with size: microphytoplankton (>20 to $200 \mu \mathrm{m})$, nanophytoplankton (>2 to $20 \mu \mathrm{m}$ ) and picophytoplankton $(<2 \mu \mathrm{m})$ (Sieburth et al. 1978). Phytoplankton size is known to affect a bivalve's ability to remove and/or ingest them, which, in turn, can affect production and condition. For example, in Polynesian lagoons devoted to pearl oyster Pinctada maxima rearing, more than $60 \%$ of the phytoplanktonic biomass and production was reported to come from cyanobacterial cells in the size range of $<2 \mu \mathrm{m}$. Pearl oysters are not efficient grazers of these small cells and, hence, production was lower than would normally be attributed to the reported phytoplankton biomass (Dupuy et al. 1999, Tomaru et al. 2002). The size of the phytoplankton available as food for Perna canaliculus may also be important to the success of mussel farms.

If Perna canaliculus are unable to efficiently remove picophytoplankton, then a significant amount of biomass in marine farms in parts of the Pelorus Sound may not be available for grazing (Safi \& Gibbs 2003). One aim of the present study was to establish whether the picophytoplankton are being efficiently removed by $P$. canaliculus or whether $P$. canaliculus supplement their diet, as other bivalves do, through the consumption of heterotrophic food sources such as microzooplankton (Dupuy et al. 1999, Wong et al. 2003) and bacteria (Pile \& Young 1999). In particular, the present study was designed to answer the question: How efficiently do $P$. canaliculus graze on picophytoplankton, bacteria and microzooplankton populations?

The assessment of the ability of Perna canaliculus to remove and utilise natural phytoplankton populations at different times of the year, and the comparison of these results with knowledge of natural assemblages in the Marlborough Sounds, will improve our ability to predict mussel growth and condition. 


\section{MATERIALS AND METHODS}

Three experiments were conducted in New Zealand's main mussel culture area, Pelorus Sound. These were designed to provide a range of natural phytoplankton assemblages (species mix and abundance). Perna canaliculus of approximately $90 \mathrm{~cm}$ in length were collected from a local mussel farm in Pelorus Sound at the time of each experiment, and represented average size and condition of mussels at the time of each experiment. The experiments were carried out in summer (November 2002), late autumn/ early winter (May 2002) and winter (June 2005).

Feeding rates and prey selection of individual Perna canaliculus were measured using a set of 12 chambers designed according to Hawkins et al. (1996). To minimise turbulence the chambers were baffled at the inflow, and the outflow water passed over a weir, which acted as a buffer ahead of the outflow pipe. The experimental chambers were located on a wharf so that seawater could be pumped directly into a header tank and then gravity fed to each of the feeding chambers. The flow rate to each chamber was maintained at approximately $200 \mathrm{ml} \mathrm{min}^{-1}$ to ensure that there was little or no recirculation.

The collected mussels were scraped free of epibiotic growth and their byssal threads carefully trimmed to make collection of faecal material easier. They were acclimatised in filtered seawater for $24 \mathrm{~h}$ before use in the experiments. The mussels were then randomly allocated to the chambers, one individual per chamber, and left to acclimatise for at least $1 \mathrm{~h}$. The production of faecal material was taken as an indication that the mussels were actively capturing food. Mussels that were not active during the acclimation period were removed and replaced. At least 2 chambers containing no mussels served as controls. At the end of the acclimatisation period, all bound faecal and pseudofaecal material was siphoned out of each chamber without disturbing the mussels. This time was recorded as $t_{0}$.

Mussel feeding behaviour changes over time, with short experiments showing different results to those from longer experiments (Riisgård \& Randløv 1981). Therefore, all experiments were run for $1 \mathrm{~h}$ only, which was long enough to gather faecal and pseudofaecal material without any change to the mussels' feeding patterns. From $t_{0}$ until the end of the experiment $\left(t_{\text {end }}\right)$, all outflow water was collected in one large container per chamber to enable mean values of all measured components to be calculated. At $t_{\text {end }}\left(1 \mathrm{~h}\right.$ after $\left.t_{0}\right)$, two 1 l water subsamples were collected from the inflow water and from each of the outflow containers of each chamber. Faeces and pseudofaeces produced over the duration of the experiment were collected into separate containers, preserved in $10 \%$ Lugol's iodine solu- tion for determination of species composition and then analysed for organic and inorganic content.

Sample preparation and preservation. The inflow and outflow water samples were well mixed and then subsampled for size-fractionated chl a, phytoplankton, microzooplankton, picophytoplankton and bacteria analyses (see individual protocols below). At the end of each experiment, the mussels were frozen for later analysis of condition, size and weight.

Chl a. Size-fractionated chl a $(>20,>5$ to $20,>2$ to 5 , $>0.2$ to $2 \mu \mathrm{m}$ ) was measured at $t_{0}$ in the inflow water and at $t_{\text {end }}$ in water collected in the outflow container of each chamber following the methods described in Safi et al. (2007).

Species composition and enumeration of phyto- and microzooplankton. Microscope analyses were used to determine phytoplankton ( $>2 \mu \mathrm{m}$ ) and microzooplankton species composition in the inflow and outflow water. The phytoplankton and microzooplankton were identified to species where possible and cellular abundance and cell size were measured to provide estimates of algal carbon following the methods described in Safi et al. (2007).

Phytoplankton species and genera were also grouped into diatoms, dinoflagellates and 'others'. 'Others' included unidentified small flagellates, (dominated by Cryptomonadaceae, Euglenaceae), Pyramimonadaceae and Dityochaceae. Fragile species, including some phytoflagellates, are difficult to distinguish when preserved in Lugol's solution (Jeffrey \& Vesk 1997) and therefore not all could be identified to genera. All plankton were divided into micro- $(>20 \mu \mathrm{m})$, nano- $(>2$ to $20 \mu \mathrm{m})$ and pico- $(<2 \mu \mathrm{m})$ size classes according to the scale of Sieburth et al. (1978). The nanophytoplankton ( $>2$ to $20 \mu \mathrm{m}$ ) were further divided into $>2$ to $5 \mu \mathrm{m}$ and $>5$ to $20 \mu \mathrm{m}$ size ranges following the reported differences in feeding retention between these size ranges by bivalves (Ward et al. 1998, Dupuy et al. 1999).

Picophytoplankton and bacterial enumeration. Additional subsamples taken from the inflow and outflow of the chambers were analysed for eukaryotic and prokaryotic picophytoplankton and bacteria. Cell numbers were determined by flow cytometry using a FACS Calibur instrument (Becton Dickinson) with CellQuest v. 3.1 software following the methods described in Safi et al. (2007). Cell carbon for eukaryotic and prokaryotic phytoplankton and bacteria were also calculated following the methods described in Safi et al. (2007).

Faeces and pseudofaeces analyses. At the end of each experiment, faeces and pseudofaeces (when produced) were collected by syringe from the bottom of the chambers and preserved with Lugol's acidified iodine solution. In the laboratory, subsamples were broken up and diluted with filtered seawater $(0.2 \mu \mathrm{m})$ and examined for phytoplankton and microzooplank- 
ton content. Once this examination was complete, the faeces were filtered onto ashed and pre-weighed Whatman GF/F 25 mm filters, rinsed with fresh water and dried for particulate analyses.

Particulate matter and mussel condition. Water and faeces samples were filtered and analysed for total particulate matter (TPM), particulate inorganic matter (PIM) and particulate organic matter (POM) following the methods described in Safi et al. (2007). Mussel condition (CI) was calculated from tissue dry weights $(T D W): C I=[T D W /(T D W+D W$ shell $)] \times 100$, following the methods described in Safi et al. (2007).

Removal rate calculations. The rates at which Perna canaliculus removed size-fractionated chl $a$, phytoplankton (>2 $\mu \mathrm{m}$, species), microzooplankton, picophytoplankton and bacteria were reported as percentage removal rates. This provided a density-independent measurement of removal efficiency on these populations, which was easily compared across experimental types and between different organisms. All rates were corrected for mussel size using Eq. (1) (see below).

Feeding rate calculations. In this study, the term 'feeding rate' refers to the net result of various feeding processes: filtration, ingestion, absorption, rejection and selection. The feeding rates (Table 1) have been adapted from Hawkins et al. (1999) and calculated using the biodeposition method as discussed by Iglesias et al. (1998). The term 'filtration rate' (FR) has been used even though technically Perna canaliculus is a suspension feeder, not a filter feeder (Shimeta \& Jumars 1991). This method assumes that ingested PIM can be used as an inert tracer, and that suspended particulates and those retained by the gill of the mussel are of similar organic content. The biodeposition method provides results equivalent to those from more conventional methods used for estimating feeding rates in closed or flow-through systems, providing the methods are followed exactly (Riisgård 2001). The main advantage of this method is that feeding responses are time-integrated and are therefore less affected by short-term variations in feeding behaviour (Iglesias et al. 1998).

The experiments were conducted with Perna canaliculus of approximately equal length but representative of the natural seasonal variation in conditions at our site and the time of year. The TDW of individuals ranged from 2.9 to $4.8 \mathrm{~g}$ (mean: $3.7 \mathrm{~g}$ ) in the first experiment, 3.7 to $5.8 \mathrm{~g}$ (mean: $4.7 \mathrm{~g}$ ) in the second experiment and 1.75 to $3.25 \mathrm{~g}$ (mean: $2.0 \mathrm{~g}$ ) in the third. To enable a comparison between experiments, the feeding rates were scaled to the mean $P$. canaliculus weight across all 3 experiments of $3.46 \mathrm{~g}$. The mean standardised feeding rates were calculated using the equation:

$$
\mathrm{R}_{\mathrm{S}}=\left(\frac{\mathrm{TDW}_{\mathrm{s}}}{\mathrm{TDW}_{\mathrm{obs}}}\right)^{b} \cdot \mathrm{R}_{\mathrm{obs}}
$$

where $R_{s}$ is the standardised feeding rate, TDW ${ }_{s}$ and $\mathrm{TDW}_{\text {obs }}$ are the tissue dry weights $(\mathrm{g})$ of the standard $(3.46 \mathrm{~g})$ and observed $P$. canaliculus, respectively, $\mathrm{R}_{\mathrm{obs}}$ is the observed feeding rate and $b$ is the average size exponent of 0.64 for feeding processes in a variety of suspension feeding bivalves (Bayne \& Newell 1983, Jørgensen 1990).

Statistical tests. Mussel condition and the various feeding rates were compared using 1-way ANOVA with post hoc least significant difference (LSD) testing using Datadesk (DataDesk 1997).

\section{RESULTS}

\section{Water quality}

The mean water temperature was $16^{\circ} \mathrm{C}$ in November, $14^{\circ} \mathrm{C}$ in May and $12^{\circ} \mathrm{C}$ in June. TPM was 33.2 $\mathrm{mg} \mathrm{l}^{-1}$ in June, $32.3 \mathrm{mg} \mathrm{l}^{-1}$ in November and $17.1 \mathrm{mg} \mathrm{l}^{-1}$ in May. In all 3 experiments POM remained at $<30 \%$ of TPM with the highest percentage of POM being reported in June $(29 \%)$ followed by November $(23 \%)$ with May being the lowest (21\%). Chl a concentrations

Table 1. Definition and calculation of the different feeding and digestion processes (after Hawkins et al. 1996, 1998, Soletchnik et al. 1996, Urrutia et al. 1996). PIM: particulate inorganic matter; POM: particulate organic matter; $f$ : the fraction that the component represents of the total diet or biodeposited dry weight

\begin{tabular}{|c|c|c|c|}
\hline Parameter & Symbol & Units & Calculation \\
\hline Filtration rate & FR & $\mathrm{mg} \mathrm{h}^{-1}$ & $\left(\mathrm{PIM}_{\text {faeces }}+\mathrm{PIM}_{\text {pseudofaeces }}\right) /\left(f \mathrm{PIM}_{\text {diet }}\right)$ \\
\hline Clearance rate & $\mathrm{CR}$ & $\mathrm{ml} \mathrm{h}^{-1}$ & FR/PIM diet \\
\hline Rejection rate & $\mathrm{RR}$ & $\mathrm{mg} \mathrm{h}^{-1}$ & mg pseudofaeces $\mathrm{h}^{-1}$ \\
\hline Fraction rejected & $f \mathrm{RR}$ & $\%$ & RR/FR \\
\hline Ingestion rate & IR & $\mathrm{mg} \mathrm{h}^{-1}$ & $(\mathrm{FR}-\mathrm{RR})$ \\
\hline Net organic ingestion rate & NOIR & $\mathrm{mg} \mathrm{h}^{-1}$ & $\left(\mathrm{FR} \times \mathrm{POM}_{\text {diet }}\right)-\left(\mathrm{RR} \times f \mathrm{POM}_{\text {pseudofaeces }}\right)$ \\
\hline Organic content of ingested matter & OCI & $\mathrm{mg} \mathrm{h}^{-1}$ & NOIR/IR \\
\hline Net organic absorption rate & NOAR & $\mathrm{mg} \mathrm{h}^{-1}$ & NOIR $-\left(\mathrm{mg}\right.$ faeces $\left.\mathrm{h}^{-1} \times f \mathrm{POM}_{\text {faeces }}\right)$ \\
\hline Net absorption efficiency from ingested organics & NAEIO & Fraction & NOAR/NOIR \\
\hline
\end{tabular}


are reported in Fig. 1. In all 3 experiments, the 0.2 to 2 $\mu \mathrm{m}$ size fraction represented the largest proportion of chl a biomass: $38 \%$ of the phytoplankton in May, $40 \%$ in November and $37 \%$ in June. This was followed by the $>20 \mu \mathrm{m}$ size fraction, which represented on average $31 \%$ of the phytoplankton in May, $26 \%$ in November and $31 \%$ in June. The lowest percentage (15\%) was reported in all experiments in the $>2$ to $5 \mu \mathrm{m}$ size fraction (see Table 3).

\section{Perna canaliculus condition}

Perna canaliculus selected for the experiment showed variation between experiments with mean ( \pm SD) shell lengths of $88 \pm 3.7 \mathrm{~mm}$ in May, $90 \mathrm{~mm} \pm$ $1.4 \mathrm{~mm}$ in June to $93 \pm 3.5 \mathrm{~mm}$ in November. Shell width and depth showed similar trends but were lowest in June. In June the lowest mussel weights were also observed. Reflecting these variations in size and weight, CI was significantly lower in June (10.9 \pm 1.5$)$ than during the other 2 experiments in May $(18 \pm 3.2)$ $\left(F_{1,16}=4.49, \mathrm{p}=3.8 \mathrm{E}-08\right)$ and November $(20 \pm 2.3)$ $\left(F_{1,16}=4.49, \mathrm{p}=1.63 \mathrm{E}-05\right)$.

\section{Feeding rates}

Calculated feeding rates are shown in Table 2 for the 3 experiments. Filtration rates (FR) were highest in June $\left(23.0 \mathrm{mg} \mathrm{h}^{-1}\right)$ followed by November $\left(18.1 \mathrm{mg} \mathrm{h}^{-1}\right)$ but were much lower in May $\left(8.8 \mathrm{mg} \mathrm{h}^{-1}\right)$. The FR rate was significantly lower in May than in November $\left(F_{1,18}=8.7\right.$, $\mathrm{p}=0.001)$ or June $\left(F_{1,16}=14.0, \mathrm{p}=0.002\right)$, but there was no significant difference between FR in November and June $\left(F_{1,16}=1.9, p=0.19\right)$. In November and May no measurable pseudofaeces were produced, but in June pseudofaeces were produced at an average rejection rate (RR) of $1.8 \mathrm{mg} \mathrm{h}^{-1}$. Clearance rates (CR), ingestion rates (IR) and net organic absorption rates (NOAR) all approximately doubled between May and November (Table 2). CR was significantly different between the 3

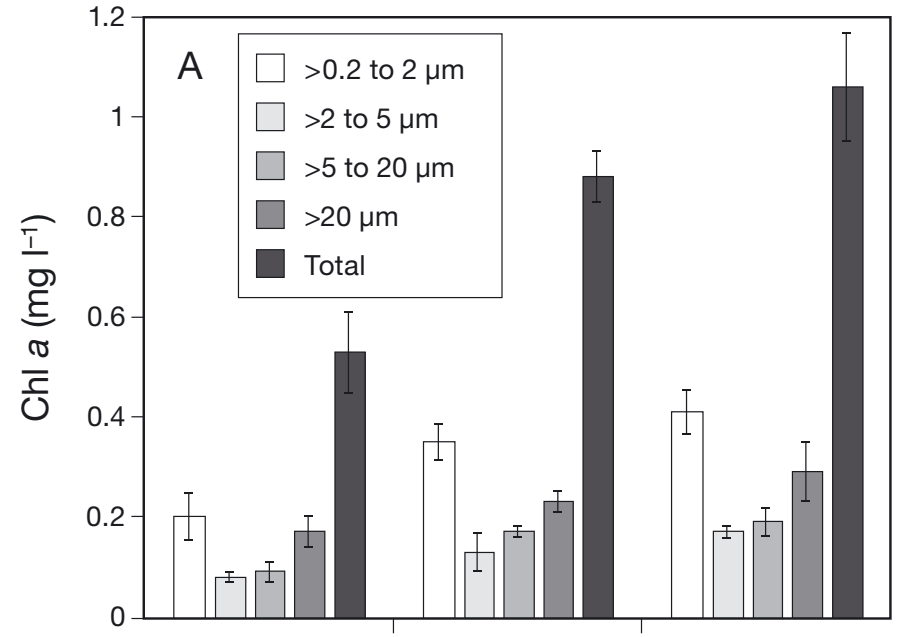

May

November

\begin{abstract}
June
\end{abstract}

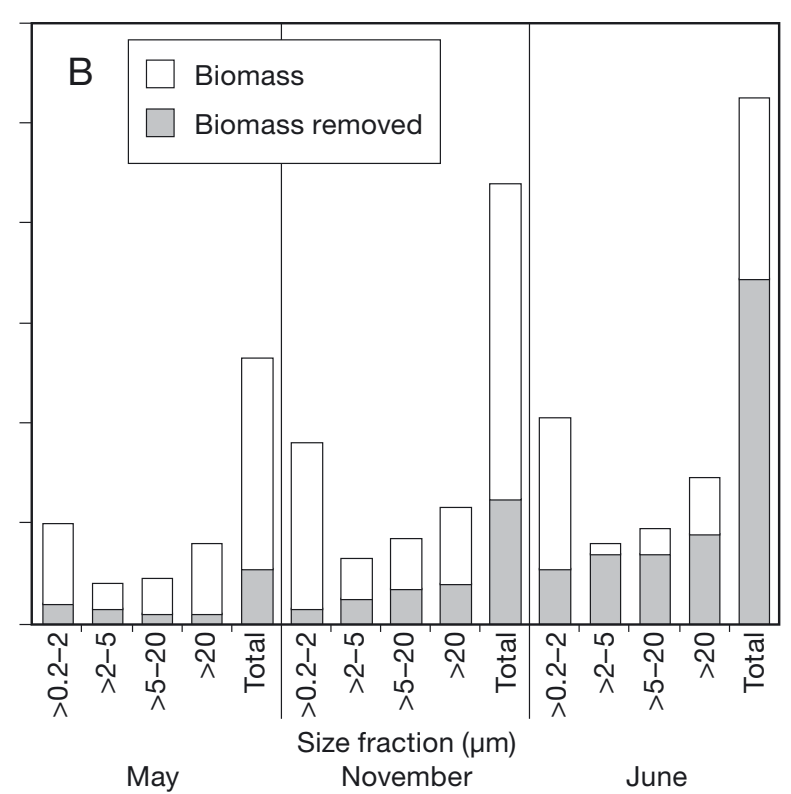

Fig. 1. Perna canaliculus. (A) Total and size-fractionated chl a (mean \pm SD) measured during 3 experiments conducted in May, November and June in Pelorus Sound. (B) Size-fractionated chl a biomass and biomass removed per size fraction by mussels during 3 grazing experiments conducted in May, November and June in Pelorus Sound

Table 2. Perna canaliculus. Calculated feeding and digestion rates in May, November and June ( $\mathrm{n}=8-9)$. Description of calculations is given in Table 1 with all rates standardised to a $3.46 \mathrm{~g}$ dry weight mussel using Eq. (1). Values are means $( \pm \mathrm{SD})$. See Table 1 for definition of abbreviations

\begin{tabular}{|c|c|c|c|c|c|c|c|c|c|}
\hline Month & $\begin{array}{c}\mathrm{FR} \\
\left(\mathrm{mg} \mathrm{h}^{-1}\right)\end{array}$ & $\begin{array}{c}\mathrm{RR} \\
\left(\mathrm{mg} \mathrm{h}^{-1}\right)\end{array}$ & $\begin{array}{l}f \mathrm{RR} \\
(\%)\end{array}$ & $\begin{array}{c}\mathrm{CR} \\
\left(\mathrm{ml} \mathrm{h}^{-1}\right)\end{array}$ & $\begin{array}{c}\mathrm{IR} \\
\left(\mathrm{mg} \mathrm{h}^{-1}\right)\end{array}$ & $\begin{array}{c}\text { NOIR } \\
\left(\mathrm{mg} \mathrm{h}^{-1}\right)\end{array}$ & $\begin{array}{l}\mathrm{OCI} \\
(\%)\end{array}$ & $\begin{array}{c}\text { NOAR } \\
\left(\mathrm{mg} \mathrm{h}^{-1}\right)\end{array}$ & $\begin{array}{c}\text { NAEIO } \\
(\%)\end{array}$ \\
\hline May & $8.8(6.3)$ & $0.0(0)$ & $0.0(0)$ & 347 (247) & $8.8(6.3)$ & $1.8(1.3)$ & $20(1.1)$ & $1.6(1.2)$ & $89(3)$ \\
\hline November & $18.1(5.9)$ & $0.0(0)$ & $0.0(0)$ & 729 (266) & $18.1(5.9)$ & 3.9 (1.9) & 21 (6.6) & $3.6(1.8)$ & $89(5)$ \\
\hline June & $23.0(9.2)$ & $1.7(1.2)$ & $8.0(5.2)$ & 2084 (1321) & $21.4(8.6)$ & $6.8(3.9)$ & $31(6.8)$ & $6.3(3.6)$ & $94(4)$ \\
\hline
\end{tabular}


experiments $\left(F_{2,24}=12.6, p=0.0001\right)$. In June mussel condition was at its lowest and while CR was over 2 times higher than in November, the IR was also higher. IR were more variable between mussels but were still significantly different between the 3 experiments $\left(F_{2,24}=7.9\right.$, $p=0.003$ ). In June the net organic ingestion rates (NOIR) were higher than in May and November; the highest rates of organic condition index (OCI) and NOAR also were observed indicating very high organic selection was occurring in June. The NOAR rates were significantly lower in May than in both November $\left(F_{1,15}=7.0\right.$, $\mathrm{p}=0.01)$ and June $\left(F_{1,17}=13.7, \mathrm{p}=0.002\right)$. The net absorption efficiency of ingested organics (NAEIO) was also highest in June for all diets (0.91, Table 2). Although Perna canaliculus showed selection of organic matter before ingestion in June only, it always showed high assimilation efficiencies (Tables $2 \& 3$ ). Significantly higher NOIR rates were observed in November and June than in May $\left(F_{1,15}=7.95, \mathrm{p}=0.01\right.$ and $F_{1,16}=13.7, \mathrm{p}=0.002$, respectively), but this result was due to the increase observed in CR.

\section{Size-fractionated chl a biomass and removal}

Chl a was lowest in May at $0.53 \mu^{\mathrm{g}^{-1}}$ and highest in June at $1.06 \mathrm{\mu g} \mathrm{l}^{-1}$ (Fig. 1). These results indicated that, on average, $20 \%$ of the phytoplankton was removed in May, $28 \%$ in November and $66 \%$ in June. Unadjusted results ( $45 \%$ in June) were all well within the general guidelines set by Widdows \& Johnson (1988), who suggested particle concentration should not be reduced by more than $50 \%$ to stop refiltration occurring within the chambers. Chl a removal was consistently highest in the $>2$ to $5 \mu \mathrm{m}$ size fraction with 43,42 and $88 \%$ on average removed in May, November and June, respectively (Figs. $1 \& 2$, Table 3). The lowest chl a removal was in the $>0.2$ to $2 \mu \mathrm{m}$ size fraction in November with only $9 \%$ on average removed (Table 3 ).

\section{Removal of phytoplankton and organic particles $<2 \mu \mathrm{m}$}

Total picophytoplankton (equivalent to $>0.2-2 \mu \mathrm{m}$ chl a) removal was lower when measured by flow cytometry in all experiments but was most similar in June (Table 3). When converted to carbon biomass, eukaryotic picophytoplankton dominated in all experiments; their contribution to total picophytoplankton

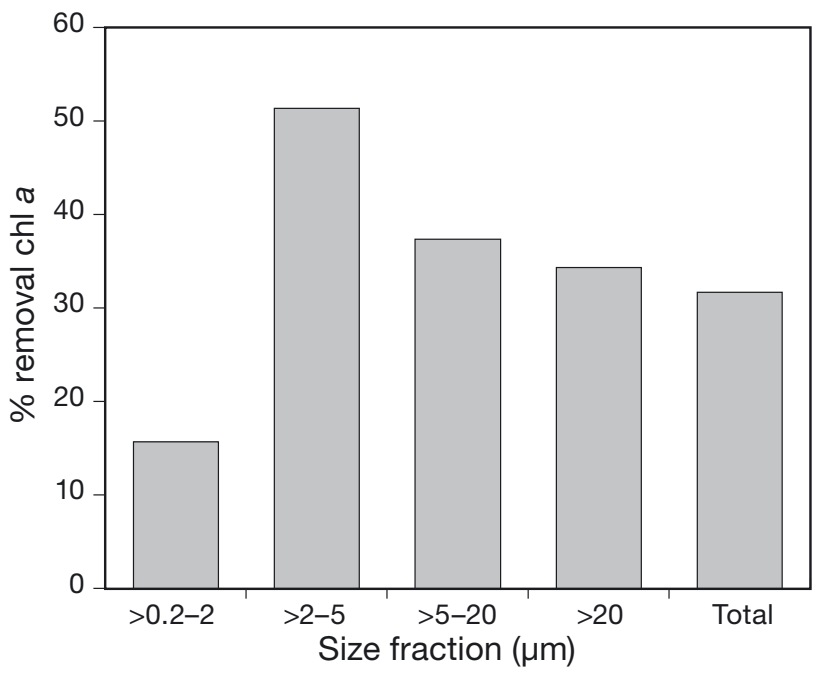

Fig. 2. Perna canaliculus. Average removal by mussels per size fraction $(\mu \mathrm{m})$ of chl a from 3 experiments in the Perlorus Sound

Table 3. Perna canaliculus. Calculated removal rates and biomass from 3 grazing experiments in Pelorus Sound conducted in May, November and June $(\mathrm{n}=8-9)$. All rates are reported as percentage removal rates, and are standardized to a $3.46 \mathrm{~g}$ dry weight mussel using Eq. (1), '+' indicates a net increase, i.e. no removal measured. Values are means $( \pm \mathrm{SD})$

\begin{tabular}{|c|c|c|c|c|c|c|}
\hline \multirow[t]{2}{*}{ Measurement type } & \multicolumn{2}{|c|}{$\longrightarrow$ May } & \multicolumn{2}{|c|}{ November } & \multicolumn{2}{|c|}{ June } \\
\hline & $\%$ removal & $\%$ biomass & $\%$ removal & $\%$ biomass & \% removal & $\%$ biomass \\
\hline \multicolumn{7}{|l|}{ Flow cytometric } \\
\hline Bacteria & $3(20)$ & & $+2(15)$ & & +1 (13) & \\
\hline Prokaryotic picophytoplankton & $+6(22)$ & 23 & $+1(10)$ & 26 & $+22(17)$ & 8 \\
\hline Eukaryotic picophytoplankton & $10(19)$ & 77 & 7 (18) & 74 & $16(20)$ & 91 \\
\hline \multicolumn{7}{|l|}{ Chl a } \\
\hline$>0.2$ to $2 \mu \mathrm{m}$ & $19(17)$ & 38 & $9(31)$ & 40 & $26(21)$ & 37 \\
\hline$>2$ to $5 \mu \mathrm{m}$ & $43(10)$ & 15 & $42(20)$ & 15 & $88(66)$ & 15 \\
\hline$>5$ to $20 \mu \mathrm{m}$ & $20(17)$ & 16 & $41(22)$ & 19 & $76(46)$ & 18 \\
\hline$>20 \mu \mathrm{m}$ & $11(16)$ & 31 & $33(13)$ & 26 & $63(31)$ & 31 \\
\hline Total & $20(13)$ & 100 & $28(22)$ & 100 & $66(26)$ & 100 \\
\hline
\end{tabular}


was highest in June at $91 \%$ compared with 77 and $74 \%$ of the total picophytoplankton carbon in May and November, respectively. Based on weighted average from counts, 6.5 and $9.1 \%$ of total picophytoplankton carbon biomass was removed in May and November, respectively, while in June $9.9 \%$ of total picophytoplankton carbon biomass was removed (Table 3). In terms of counts, total picophytoplankton represented $27 \%$ of the measured planktonic carbon biomass in May and 55 and $54 \%$ in November and June, respectively. The smallest organic particles measured during the experiment were bacteria and, on average, there was a small reduction in numbers in May of $3 \%$ and June of $1 \%$, and a small increase in numbers of $2 \%$ in November. When converted to carbon, bacteria represented $26 \%$ of the measured planktonic carbon biomass in counts in May, and 15 and $20 \%$ of the measured planktonic carbon biomass in November and June, respectively.

\section{Grazing of phytoplankton ( $>2 \mu \mathrm{m})$ and microzooplankton}

Here we assumed that any organisms removed or captured but not rejected in measured pseudofaeces were ingested. When phytoplankton species counts were converted to carbon biomass, the results indi- cated that, for the $>2 \mu \mathrm{m}$ phytoplankton size fraction, $31 \%$ was grazed in May, $22 \%$ in November, while $49 \%$ (excluding pseudofaeces produced) was grazed in June. This was higher than the 20 and $28 \%$ removal reported on chl $a$ for $>2 \mu \mathrm{m}$ the size fractions in May and November, respectively, but lower than the $66 \%$ reported in June (Table 3). No collectable quantities of pseudofaeces were produced in May and November, indicating that for these experiments the species removed were ingested. In June examination of pseudofaeces indicated some larger species were being rejected; these included Coscinodiscus sp., Rhizosolenia styliformis, Ditylum brightwelli and Ceratium furca as well as some smaller species including Pseudo-nitzschia sp. and Navicula sp. Some smaller Thalassiosira sp. were also observed in 2 pseudofaeces counts, but this genus was not consistently observed. When results were considered in terms of carbon ingested, small flagellates represented the largest source of carbon provided by plankton species in May (33\%), followed by the ciliate Myrionecta rubra (13\%), the dinoflagellate Ceratium furca $(6 \%)$ and the diatom Chaetocerous sp. (4\%) (Table 4). In November the potentially toxic diatom Pseudo-nitzschia seriata dominated the biomass and represented the largest source of carbon, comprising $36 \%$ of the grazed carbon, followed by the dinoflagellates Dinophysis sp. (27\%), Gyrodinium

Table 4. Planktonic taxa $>2 \mu \mathrm{m}$ observed in the May grazing experiment

\begin{tabular}{|c|c|c|c|c|c|c|}
\hline Planktonic taxa $>2 \mu \mathrm{m}$ & Division & Family & $\begin{array}{l}\text { Size class } \\
\qquad(\mu \mathrm{m})\end{array}$ & $\begin{array}{l}\text { \% carbon } \\
\text { contribution } \\
\text { to biomass }\end{array}$ & $\%$ grazed & $\begin{array}{c}\% \text { carbon } \\
\text { contribution to } \\
\text { biomass grazed }\end{array}$ \\
\hline Small flagellates & Other & $\begin{array}{l}\text { Dityochaceae, Crypto- } \\
\text { monadaceae, Euglenaceae }\end{array}$ & $>2$ to 5 & 21 & 37 & 33 \\
\hline Myrionecta rubra & Ciliate & Mesodiniidae & $>20$ to 200 & 10 & 64 & 13 \\
\hline Ceratium furca & Dinoflagellate & Ceratiaceae & $>20$ to 200 & 2 & 45 & 6 \\
\hline Chaetoceros spp. & Diatom & Chaetocerotaceae & $>5$ to 20 & 5 & 71 & 4 \\
\hline Akashiwo sanguinea & Dinoflagellate & Gymnodiniaceae & $>20$ to 200 & 8 & 13 & 2 \\
\hline Coscinodiscus sp. & Diatom & Coscinodiscaceae & $>200$ & 7 & 8 & 2 \\
\hline Dictyocha speculum & Other & Dityochaceae & $>20$ to 200 & 3 & 19 & 1 \\
\hline Ceratium tripos & Dinoflagellate & Ceratiaceae & $>20$ to 200 & 2 & 21 & 1 \\
\hline Thalassiosira spp. & Diatom & Thalassiosiraceae & $>20$ to 200 & 2 & 52 & 1 \\
\hline Climacosphenia sp. & Diatom & Chaetocerotaceae & $>20$ to 200 & 2 & 36 & 1 \\
\hline Pseudo-nitzschia seriata & Diatom & Bacillariaceae & $>5$ to 20 & 2 & 32 & 1 \\
\hline Odontella sp. & Diatom & Eupodiscaceae & $>200$ & 2 & 32 & 1 \\
\hline Scrippsiella trochoidea & Dinoflagellate & Calciodinellaceae & $>5$ to 20 & 2 & 80 & 1 \\
\hline Eucampia sp. & Diatom & Biddulphiaceae & $>20$ to 200 & 2 & 84 & 1 \\
\hline Ditylum brightwellii & Diatom & Lithodesmiaceae & $>20$ to 200 & 7 & $<1$ & $<1$ \\
\hline Pronoctiluca sp. & Dinoflagellate & Noctilucaceae & $>20$ to 200 & 7 & $<1$ & $<1$ \\
\hline Chaetoceros teres & Diatom & Chaetocerotaceae & $>20$ to 200 & 3 & $<1$ & $<1$ \\
\hline Karenia spp. & Dinoflagellate & Gymnodiniaceae & $>5$ to 20 & 2 & 1 & $<1$ \\
\hline Hemiaulus spp. & Diatom & Hemiaulaceae & $>5$ to 20 & 1 & 54 & $<1$ \\
\hline Leptocylindrus danicus & Diatom & Leptocylindraceae & $>5$ to 20 & 1 & 66 & $<1$ \\
\hline
\end{tabular}


spirale (4\%) and Scrippsiella trochoidea (3\%) (Table 5). Small flagellates also contributed $3 \%$ of the biomass grazed. In June, Thalassiosira spp. represented the largest source of carbon provided by a single plankton genus (32\%), followed by the small flagellates $(12 \%)$, then the small $(<20 \mu \mathrm{m})$ oligotrich ciliates $(7 \%)$ and the dinoflagellates Dinophysis (3\%) (Table 6). Some Thalassiosira species were also seen in pseudofaeces in June, but only in small numbers, despite their high abundance at this time.

In all faecal samples some phytoplankton ingested were still identifiable, indicating that these species may have passed through the stomach undigested. These included the dinoflagellate species, Scrippsiella trochoidea and Protoperidinium spp., and the diatom species, Paralia sp. and Nitzschia spp. Of these, only $S$. trochoidea was a significant contributor to the carbon biomass grazed. S. trochoidea and Protoperidinium spp. both appeared to be becoming encysted while Paralia sp. and the small pennate diatoms, predominately Nitzschia spp., still appeared viable. Furthermore prokaryotic picophytoplankton were also observed in the faeces.

Microscope counts revealed that ciliates represented 14,11 and $7 \%$ of the available planktonic carbon from the $>2 \mu \mathrm{m}$ size fraction in May, November and June, respectively. Ciliates represented 23, 9 and $19 \%$ of the grazed planktonic carbon biomass from the $>2 \mu \mathrm{m}$ size fraction in May, November and June, respectively. The results indicate that all ciliate microzooplankton ob- served appear to be readily grazed. No ciliates were found in the pseudofaeces.

\section{Planktonic divisions grazed}

In May the largest proportion of the carbon grazed (38\%) came from diatoms, followed by others (dominated by small flagellates) $(27 \%)$, ciliates $(20 \%)$ and dinoflagellates $(14 \%)$. In November diatoms represented $68 \%$ of the carbon grazed followed by $14 \%$ for dinoflagellates, $10 \%$ for others and $9 \%$ for ciliates. Excluding the pseudofaeces produced in June, diatoms again contributed the majority of the carbon grazed: $43 \%$ followed by $20 \%$ for dinoflagellates, $19 \%$ for ciliates and $18 \%$ for others

\section{Microbial contributions to size fraction}

The $>2$ to $5 \mu \mathrm{m}$ fraction was dominated by small flagellates; this group was a significant contributor to both the carbon available and the carbon grazed in May and June but was less prominent in November. The $>5$ to $20 \mu \mathrm{m}$ size fraction was dominated by small diatoms such as Pseudo-nitzschia seriata, Chaetocerous sp., and Leptocylindricus danicus as well as some smaller dinoflagellates such as Scrippsiella trochoidea and Karenia spp. in all 3 experiments. Within the $>5$ to $20 \mu \mathrm{m}$ size fraction, $S$. trochoidea made up the largest

Table 5. Planktonic taxa $>2 \mu \mathrm{m}$ observed in the November grazing experiment

\begin{tabular}{|c|c|c|c|c|c|c|}
\hline Planktonic taxa $>2 \mu \mathrm{m}$ & Division & Family & $\begin{array}{l}\text { Size class } \\
\quad(\mu \mathrm{m})\end{array}$ & $\begin{array}{c}\text { \% carbon } \\
\text { contribution } \\
\text { to biomass }\end{array}$ & \% grazed & $\begin{array}{c}\% \text { carbon } \\
\text { contribution to } \\
\text { biomass grazed }\end{array}$ \\
\hline Pseudo-nitzschia seriata & Diatom & Bacillariaceae & $>5$ to 20 & 33 & 29 & 36 \\
\hline Dinophysis sp. & Dinoflagellate & Dinophysaceae & $>20$ to 200 & 8 & 82 & 24 \\
\hline Gyrodinium spirale & Dinoflagellate & Gymnodiniaceae & $>20$ to 200 & 6 & 25 & 4 \\
\hline Scrippsiella trochoidea & Dinoflagellate & Calciodinellaceae & $>5$ to 20 & 4 & 38 & 3 \\
\hline Small flagellates & Other & $\begin{array}{l}\text { Dityochaceae, Crypto- } \\
\text { monadaceae, Euglenaceae }\end{array}$ & $>2$ to 5 & 5 & 26 & 3 \\
\hline Large Strombidium spp. & Cilliate & Strombidiidae & $>20$ to 200 & 10 & 10 & 2 \\
\hline Thalassiosira sp & Diatom & Thalassiosiraceae & $>20$ to 200 & 5 & 22 & 1 \\
\hline Thalassionema nitzschioides & Diatom & Thalassionemateceae & $>5$ to 20 & 2 & 60 & 1 \\
\hline Chaetoceros spp. & Diatom & Chaetocerotaceae & $>5$ to 20 & 2 & 27 & $<1$ \\
\hline Leptocylindrus sp. & Diatom & Melosiraceae & $>5$ to 20 & 2 & 23 & $<1$ \\
\hline Unknown diatoms & Diatom & Unknown diatoms & $>5$ to 20 & 1 & 25 & $<1$ \\
\hline Ditylum brightwellii & Diatom & Lithodesmiaceae & $>20$ to 200 & 2 & 14 & $<1$ \\
\hline Leptocylindricus danicus & Diatom & Leptocylindraceae & $>5$ to 20 & 3 & 10 & $<1$ \\
\hline Unknown dinoflagellates & Dinoflagellate & Dinoflagellate & $>20$ to 200 & 0 & 82 & $<1$ \\
\hline Rhizosolenia imbricata & Diatom & Rhizosoleniaceae & $>20$ to 200 & 1 & 16 & $<1$ \\
\hline Nitzschia closterium & Diatom & Bacillariaceae & $>5$ to 20 & 0 & 45 & $<1$ \\
\hline Nitzschia spp. & Diatom & Bacillariaceae & $>5$ to 20 & 0 & 41 & $<1$ \\
\hline Nitzschia membranacea & Diatom & Bacillariaceae & $>20$ to 200 & 0 & 11 & $<1$ \\
\hline Cerataulina spp. & Diatom & Hemiaulaceae & $>20$ to 200 & 1 & 1 & $<1$ \\
\hline
\end{tabular}


Table 6. Planktonic taxa $>2 \mu \mathrm{m}$ observed in the June grazing experiment

\begin{tabular}{|c|c|c|c|c|c|c|}
\hline Planktonic taxa $>2 \mu \mathrm{m}$ & Division & Family & $\begin{array}{l}\text { Size class } \\
\quad(\mu \mathrm{m})\end{array}$ & $\begin{array}{c}\text { \% carbon } \\
\text { contribution } \\
\text { to biomass }\end{array}$ & \% grazed & $\begin{array}{c}\text { \% carbon } \\
\text { contribution to } \\
\text { biomass grazed }\end{array}$ \\
\hline Thalassiosira spp. & Diatom & Thalassiosiraceae & $>20$ to 200 & 15 & 100 & 32 \\
\hline Small flagellates & Other & $\begin{array}{l}\text { Dityochaceae, Crypto- } \\
\text { monadaceae, Euglenaceae }\end{array}$ & $>2$ to 5 & 14 & 53 & 13 \\
\hline Oligotrichs $<20 \mu \mathrm{m}$ & Ciliate & Oligotrichia & $>5$ to 20 & 12 & 43 & 7 \\
\hline Rhizosolenia styliformis & Diatom & Rhizosoleniaceae & $>20$ to 200 & 11 & 85 & 14 \\
\hline Dinophysis sp. & Dinoflagellate & Dinophysaceae & $>20$ to 200 & 5 & 85 & 4 \\
\hline Lauderia annulata & Diatom & Thalassiosiraceae & $>20$ to 200 & 4 & 72 & 2 \\
\hline Undella sp. & Ciliate & Undellidae & $>20$ to 200 & 1 & 100 & 2 \\
\hline Amphidinium spp. & Dinoflagellate & Gymnodiniaceae & $>5$ to 20 & 4 & 35 & 1 \\
\hline Oligotrichs $>20 \mu \mathrm{m}$ & Ciliate & Oligotrichia & $>20$ to 200 & 3 & 60 & 1 \\
\hline Pseudo-nitzschia sp. & Diatom & Bacillariaceae & $>5$ to 20 & 3 & 98 & 1 \\
\hline Strombidium $<20 \mu \mathrm{m}$ & Ciliate & Strombidiidae & $>5$ to 20 & 3 & 96 & 1 \\
\hline Leptocylindrus danicus & Diatom & Leptocylindraceae & $>5$ to 20 & 3 & 87 & 1 \\
\hline Karenia spp. & Dinoflagellate & Gymnodiniaceae & $>5$ to 20 & 3 & 55 & 1 \\
\hline Scrippsiella trochoidea & Dinoflagellate & Calciodinellaceae & $>5$ to 20 & 2 & 66 & 1 \\
\hline Chaetoceros affinis & Diatom & Chaetocerotaceae & $>5$ to 20 & 2 & 100 & 1 \\
\hline Strobilidium $>20 \mu \mathrm{m}$ & Ciliate & Strombidiidae & $>20$ to 200 & 2 & 50 & $<1$ \\
\hline Ceratium tripos & Dinoflagellate & Ceratiaceae & $>20$ to 200 & 2 & 100 & $<1$ \\
\hline Gyrodinium spirale & Dinoflagellate & Gymnodiniaceae & $>20$ to 200 & 2 & 63 & $<1$ \\
\hline Pyramimonas sp. & Other & Pyramimonadaceae & $>5$ to 20 & 1 & 29 & $<1$ \\
\hline Ditylum brightwellii & Diatom & Lithodesmiaceae & $>20$ to 200 & 1 & 62 & $<1$ \\
\hline Chaetoceros debilis & Diatom & Chaetocerotaceae & $>20$ to 200 & 1 & 58 & $<1$ \\
\hline Gonyaulax polygramma & Dinoflagellate & Gonyaulacaceae & $>20$ to 200 & 1 & 60 & $<1$ \\
\hline Torodinium spp. & Dinoflagellate & Gymnodiniaceae & $>20$ to 200 & 1 & 77 & $<1$ \\
\hline Thalassionema nitzschioides & Diatom & Thalassionemateceae & $>5$ to 20 & 1 & 79 & $<1$ \\
\hline
\end{tabular}

contribution to biomass and mussel diet in November, while Chaetocerous sp. were important in May and Pseudo-nitzschia in June. In all 3 experiments the $>20 \mu \mathrm{m}$ size fraction contained a mix of phytoplankton genera and ciliates. The phototrophic ciliate Myrionecta rubra dominated this size fraction in May when biomass was low. Ciliates again dominated in November when the large ciliate Strombidium spp. dominated the $>20 \mu \mathrm{m}$ biomass, but the dinoflagellates Dinophysis and Gyrodinium sp. were more heavily grazed. In June, however, the $>20 \mu \mathrm{m}$ biomass was dominated by large diatom species, including $R$ hizosolenia styliformis and Lauderia annulata, while large oligotrichs were also important.

\section{DISCUSSION}

In the present study, we aimed to assess the utilisation of natural phytoplankton, bacterial and microzooplankton populations by the mussel Perna canaliculus. The 3 experiments, run at different times of the year, provided different planktonic community structures on each occasion. Local mussels collected from a nearby farm were approximately the same size, but reflected seasonal differences, with a signifi- cant difference in mussel condition observed in June. To overcome differences in condition, all rates were standardised to a mean mussel dry weight derived from across all 3 experiments. Given the differences in diet and condition, some interesting variations were seen in the results. Standardised CR varied by a factor of 6 (347 to $2084 \mathrm{ml} \mathrm{h}^{-1}$ ) between experiments but were well within the range reported in previous studies involving P. canaliculus (Hawkins et al.1999, Hatton 2000, Ren et al. 2006). The differences in CR appeared to reflect a combination of mussel condition (lowest in June) and food availability (highest in June). Measurable pseudofaeces production was low and occurred only in the June experiment (RR of $8 \%$ ) when large diatoms dominated the planktonic biomass. The low rates of pseudofaeces production observed did not appear to affect NAEIO, which was high in all 3 experiments (0.89 to 0.94 ) indicating that $P$. canaliculus was probably exhibiting some preferential selection and ingestion of seston, as described by Ren et al. (2006). Loosely bound pseudofaeces, or non-measurable bound quantities of pseudofaeces (Ward \& Shumway 2004), are likely to have been produced in May and November, but their quantities are unlikely to have had a significant effect on our results. 


\section{Perna canaliculus grazing on picophytoplankton and organic particles $<2 \mu \mathrm{m}$}

Previous studies in this area (Safi \& Gibbs 2003) found $<2 \mu \mathrm{m}$ picophytoplankton and organic particles often dominated biomass in these waters and one of the aims of the present study was to explore whether this small size fraction was being efficiently removed. Results of this study indicated that Perna canaliculus does not efficiently remove and ingest $>0.2$ to $2 \mu \mathrm{m}$ seston (picophytoplankton and bacteria) and removal rates were significantly lower than that observed for plankton > $2 \mu \mathrm{m}$ (Fig. 2, Table 3).

There were also large differences in removal rates of eukaryotic picophytoplankton and prokaryotic picophytoplankton between samplings. The results suggest that removal efficiency in prokaryotic picophytoplankton is lower than in eukaryotic picophytoplankton, which is probably a function of sizeas eukaryotic picophytoplankton ( 900 fg $\mathrm{C} \mathrm{cell}^{-1}$ ) are consistently larger than prokaryotic picophytoplankton $(\sim 250 \mathrm{fg} \mathrm{C}$ cell $\left.{ }^{-1}\right)$. Prokaryotic picophytoplankton could be observed within the faeces, indicating that at least some of this group, even if ingested (perhaps from aggregates), were not being fully digested. In addition, there was no overall decrease in cell numbers in the smaller sized bacteria, suggesting that their small size prevented them from being effectively removed and used as a direct source of nutrition for Perna canaliculus. These results concur with studies that show that filtration/removal efficiency decreases for most bivalves within a size range of around 1 to $7 \mu \mathrm{m}$, depending on the bivalve species (Ward \& Shumway 2004). James et al. (2001) reported $P$. canaliculus could remove particles efficiently down to $5 \mu \mathrm{m}$. The results of Møhlenberg \& Riisgård (1978) and Riisgård (1988) suggest that retention efficiency is, in part, dependent on the morphology of the laterofrontal cilia of the ctenidium. More complex laterofrontal cirri are reported to have retained particles $>4 \mu \mathrm{m}$ with almost $100 \%$ efficiency (Jørgensen et al. 1984, Jørgensen 1990) whereas simple cirri may not filter this efficiently until particles are $>7 \mu \mathrm{m}$. Our results suggest that $P$. canaliculus is efficient for particles down to around $3 \mu \mathrm{m}$, with high efficiency reported on the 2 to $5 \mu \mathrm{m}$ size fraction but dropping significantly on the 0.2 to $2 \mu \mathrm{m}$ fraction. In terms of feeding physiology, our results suggest the ctenidium function of $P$. canaliculus may be more like Mytilus edulis, which is reported to not remove bacterioplankton, as opposed to Geukensia demissa, which is re ported to efficiently remove these fine particles (Langdon \& Newell 1990). It has been reported that some bivalves can use picophytoplankton and bacteria to supplement their diet (Langdon \& Newell 1990, Kreeger \& Newell 1996, 2001, Ward et al. 1998), but it appears $P$. canaliculus cannot effectively utilise these populations, at least directly.

Bivalves also access picophytoplankton and organic particles $<2 \mu \mathrm{m}$ via ingestion of aggregates (Kach \& Ward 2008, Li et al. 2008), with aggregates likely to be broken down by the action of cilia on the gills and labial palps and the constituent particles ingested (Ward et al. $1993,1994)$. Some of the aggregated material is likely to be rejected as pseudofeces, but some may also be ingested. In the present study the reported uptake of picophytoplankton and bacterial particles may in fact reflect a portion of aggregated uptake rather than individual particle removal. We may, however, also have reduced the levels of weakly aggregated particles present in natural water by pumping our supply water into our tanks and chambers. In either case the majority of picoplankton biomass found in this area will be freely suspended.

Because picophytoplankton are known to dominate phytoplankton in the region where this study was conducted (Safi \& Gibbs 2003), these results have important implications for Perna canaliculus growth. A study on Polynesian lagoons (Dupuy et al. 1999) found bivalve production was lower than expected due to inefficient grazing of picophytoplankton, which was $60 \%$ of the planktonic biomass. In the present study, bacterial biomass was also a significant contributor to organic carbon (15 to $26 \%$ ), suggesting that $P$. canaliculus may be disadvantaged by their inefficient removal of the picoplankton size class. P. canaliculus, however, may gain access to this biomass through secondary grazing on microzooplankton, nanoflagellate grazers and grazing on aggregates.

\section{Perna canaliculus grazing on microzooplankton}

Perna canaliculus efficiently removed and appeared to ingest a range of microzooplankton species. Recent evidence indicates that microzooplankton and zooplankton, which have not traditionally been considered as food for bivalves, can be a significant contributor to bivalve nutrition (Kreeger \& Newell 1996, 2001, Dupuy et al. 1999, Wong et al. 2003). Zeldis et al. (2004) reported that $P$. canaliculus was capable of ingesting zooplankton. In the present study, ciliated microzooplankton represented between 7 and $14 \%$ of the available $>2 \mu \mathrm{m}$ planktonic carbon biomass in experiments, which, although a significant portion, is lower than observed in some New Zealand estuarine environments, where ciliates contribute $\sim 48 \%$ of the total carbon biomass $>2 \mu \mathrm{m}$ (Safi et al. 2007). The ciliates were readily removed and appeared to be ingested at rates similar to or higher than phytoplankton species (Tables 4 to 6). The high rates of removal of species such as Myrionecta rubra suggest some spe- 
cies may even be preferentially ingested over other planktonic prey. This is possibly due to a higher nutritional value and carbon content being reported in some ciliates over phytoplankton, such as diatoms, which can have lower values due to their substantial silicon frustules (Heinbokel 1978, Dupuy et al. 1999). Furthermore, by consuming microzooplankton, $P$. canaliculus are able to access bacteria and picophytoplankton indirectly. As well as ciliates, other heterotrophic and mixotrophic plankton were also observed in this study; most notable were the large dinoflagellates, Gyrodinium spirale and Dinophysis spp., as well as the smaller Karenia spp. and Amphidium sp., all of which have heterotrophic and mixotrophic forms. It was not possible to determine whether the cells observed during this study were heterotrophic because of their preservation in Lugol's iodine. This problem also applied to the heterotrophic nanoflagellate population, which was likely to represent about one third to half of the flagellates reported in this study (Safi \& Hall 1997)

\section{Removal of phytoplankton and organic particles $>2 \mu \mathrm{m}$}

Perna canaliculus generally grazed most particles $>2 \mu \mathrm{m}$ but amongst these there was evidence of selection by type (e.g. diatom, dinoflagellate, other) as well as by size. Few small particles in the 2 to $20 \mu \mathrm{m}$ range were rejected compared with the $>20 \mu \mathrm{m}$ size fraction. Standardised NOIR in June, however, was significantly higher than NOIR in November and May, suggesting that rejection was not affected by food quality.

Overall, our results are similar to those of Widdows et al. (1979) and Defossez \& Hawkins (1997) who reported ingestion preferences in other bivalve species. Perna canaliculus appeared to preferentially ingest flagellated cells, including the dinoflagellate species Akashiwo sanguinea, Gryrodinium spirale, Dinophysis spp., Amphidium and Karenia spp., as well as a number of other small flagellates dominated by small dinoflagellates. The selection of flagellated species over others may reflect similar preferences to those reported by Shumway et al. $(1985 a, b)$, and is consistent with reports that dinoflagellates have higher carbon ratios and may be more nutritious than faster growing diatoms (Montagnes et al. 1994, Menden-Deuer \& Lessard 2000). Ren et al. (2006) also found that assimilation efficiency varied with algal species, but this was significantly higher for mussels fed dinoflagellates $(84.5 \%)$ than flagellates $(77.9 \%)$ or diatoms (61.7\%). In contrast, Mons et al. (1998) and Chauvaud et al. (2001) reported rejection of toxic dinoflagellate species. In the present study, Perna canaliculus did not appear to reject Karenia spp., Dinophysis spp. or Heterocapsa triquetra, all of which are known to pro- duce toxins. Diatoms were consistently ingested in the present study, but during June some larger species, including Cosinodiscus sp., Rhizosolenia setigera and Ditylum brightwelli, as well as some smaller pennate diatoms, including Pseudo-nitzschia sp. and Navicula sp., were rejected into mucus-bound pseudofaeces, suggesting these were not the preferred food source. Cell numbers passing through the gut and remaining intact were very low in faeces in all experiments. Protoperidinium sp. and Scrippsiella trochoidea were observed in faeces but appeared to be in an encysted state. Also observed were some heavily silicified Paralia sp. and some small pennates such as Navicula spp. and Nitzchia sp., which also appeared to be viable. Some larger diatoms were also observed, but these were mostly only frustule remnants of cells. Diatoms are recognised as an important component of the bivalve diet and it was therefore surprising to find some of these species well represented in pseudofaeces, and even some apparent in faeces. The reasons for this may be a preference for higher nutritional value (dinoflagellates over diatoms) or may be due to the physical properties of the cells, including shape and carbon to silica ratios (Tomas 1997).

\section{CONCLUSIONS}

Previous work has shown phytoplankton biomass alone cannot predict condition in the bivalve mussel Perna canaliculus. Our results show that $P$. canaliculus appears to be capable of grazing on a wide range of planktonic cells to supplement its nutritional requirements, but as with many other species of bivalve, it is less efficient at retaining picoplankton particles $>0.2$ to $2 \mu \mathrm{m}$ in diameter, while particles $>2 \mu \mathrm{m}$ in size are preferred. Because the picophytoplankton and bacteria make up a significant proportion of the planktonic biomass in Pelorus Sound for much of the year, the results indicate that $P$. canaliculus must access this valuable resource via other means. This includes access through the microbial food web by grazing on microzooplankton populations, which are known to be efficient grazers of picophytoplankton and bacteria. P. canaliculus may also access these populations by grazing on aggregates; however, the abundance of this resource is unknown in this area. Our results confirm this supposition with high removal and apparent ingestion rates observed on the ciliate and nanoflagellate populations (small flagellates plus small species such as Karenia spp. and Amphidinium sp.) as well as large heterotrophic dinoflagellates (Gryrodinium spirale, Dinophysis spp.). P. canaliculus rarely produced measurable pseudofaeces, but when they did it contained predominately larger and perhaps less easily digestible diatom species, suggesting that these were less preferred prey. 
Acknowledgements. We thank 4 anonymous reviewers and J. Hewitt and K. Thompson for their helpful comments on the manuscript. We also acknowledge help in the field by J. Ren and K. Robinson from the Hamilton NIWA chemistry lab for assistance with analysis. This work was funded by the Foundation for Research Science and Technology (Contract CO1X0507).

\section{LITERATURE CITED}

Bayne BL, Newell RC (1983) Physiological energetics of marine molluscs. In: Salevddin ASM, Wilbur KM (eds) The mollusca. Physiology. Part 1, Vol 4, Academic Press, New York, NY

> Cahoon LB, Owen DA (1996) Can suspension feeding by bivalves regulate phytoplankton biomass in Lake Waccamaw, North Carolina? Hydrobiologia 325:193-200

Chauvaud L, Donval A, Thouzeau G, Paulet YM, Nezah E (2001) Variations in food intake of Pecten maximus (L.) from the Bay of Brest (France): influence of environmental factors and phytoplankton species composition. C R Acad Sci Serie III Sci Vie 324:743-755

Cloern JE (1982) Does the benthos control phytoplankton biomass in south San Francisco Bay? Mar Ecol Prog Ser 9: 191-202

DataDesk (1997) DataDesk v.6.1. DataDesk, Ithaca, NY

> Defossez JM, Hawkins AJS (1997) Selective feeding in shellfish: size-dependent rejection of large particles within pseudofaceces from Mytilus edulis, Ruditapes philippinarum and Tapes decussates. Mar Biol 129:139-147

Dupuy C, Le Gall S, Hartmann J, Bel Hassen M (1999) Protists as a trophic link between picocyanobacteria and the filter-feeding bivalve Crassostrea gigas. Bibliotheque Monaco, Inst Oceanographique, Special Issue Number 19:533-540

Espinosa EP, Perrigault M, Ward JE, Shumway SE, Allam B (2009) Lectins associated with the feeding organs of the oyster Crassostrea virginica can mediate particle selection. Biol Bull (Woods Hole) 217:130-141

Espinosa EP, Perrigault M, Ward JE, Shumway SE, Allam B (2010) Microalgal cell surface carbohydrates as recognition sites for particle sorting in suspension-feeding bivalves. Biol Bull (Woods Hole) 218:75-86

> Gardner JPA (2002) Effects of seston variability on the clearance rate and absorption efficiency of the mussels Aulacomya maoriana, Mytilus galloprovincialis and Perna canaliculus from New Zealand. J Exp Mar Biol Ecol 268: 83-101

Hatton S (2000) Effects of food concentration and food quality on the feeding behaviour of the greenshell mussel, Perna canaliculus. MSc thesis, University of Canterbury

$>$ Hawkins AJS, Smith RFM, Bayne BL, Heral M (1996) Novel observations underlying the fast growth of suspensionfeeding shellfish in turbid environments: Mytilus edulis. Mar Ecol Prog Ser 131:179-190

> Hawkins AJS, Bayne BL, Bougrier S (1998) Some general relationships in comparing the feeding physiology of suspension-feeding bivalve molluscs. J Exp Mar Biol Ecol 219:87-103

> Hawkins AJS, James MR, Hickman RW, Hatton S, Weatherhead M (1999) Modelling of suspension-feeding and growth in the green-lipped mussel Perna canaliculus exposed to natural and experimental variations of seston availability in the Marlborough Sounds, New Zealand. Mar Ecol Prog Ser 191:217-232

Heinbokel JF (1978) Studies on the functional role of tintin- nids in the southern California Bight. I. Grazing and growth rates in laboratory cultures. Mar Biol 47:177-189 Hickman RW, Waite RP, Illingworth J, Meredyth-Young JL, Payne G (1991) The relationship between farmed mussels, Perna canaliculus, and available food in PelorusKenepuru Sound, New Zealand, 1983-1985. Aquaculture 99:49-68

Iglesias JIP, Urrutia MB, Navarro E, Ibarrola I (1998) Measuring feeding and absorption in suspension-feeding bivalves: an appraisal of the biodeposition method. J Exp Mar Biol Ecol 219:71-86

James MR, Weatherhead MA, Ross AH (2001) Size-specific clearance, excretion, and respiratory rates, and phytoplankton selectivity for the mussel Perna canaliculus at low levels of natural food. NZ J Mar Freshw Res 35:73-86

Jeffrey SW, Vesk M (1997) Introduction to marine phytoplankton and their pigment signatures. In: Jeffrey SW, Mantoura RFC, Wright SW (eds) Phytoplankton pigments in oceanography: guidelines to modern methods. UNESCO Monogr Oceanogr Methodol 10, Paris, p 37-84

> Jørgensen CB, Kiørboe T, Møhlenberg F, Riisgård HU (1984) Ciliary and mucus-net filter feeding, with special reference to fluid mechanical characteristics. Mar Ecol Prog Ser 15:283-292

Jørgensen CB (1990) Bivalve filter feeding: hydrodynamics, bioenergetics, physiology, and ecology. Olsen \& Olsen, Fredensborg

Kach DJ, Ward JE (2008) The role of marine aggregates in the ingestion of picoplankton-size particles by suspensionfeeding molluscs. Mar Biol 153:797-805

> Kreeger DA, Newell RIE (1996) Ingestion and assimilation of carbon from cellulolytic bacteria and heterotrophic flagellates by the mussels Geukensia demissa and Mytilus edulis (Mollusca: Bivalvia). Aquat Microb Ecol 11:205-214

Kreeger DA, Newell RIE (2001) Seasonal utilization of different seston carbon sources by the ribbed mussel, Geukensia demissa (Dillwyn) in a mid-Atlantic salt marsh. J Exp Mar Biol Ecol 260:71-91

Lalli CM, Parsons TR (1997) Biological oceanography: an introduction, 2nd edn. Butterworth-Heinemann, Oxford

> Langdon CJ, Newell RIE (1990) Utilization of detritus and bacteria as food sources by two bivalve suspension-feeders, the oyster Crassostrea virginica and the mussel Geukensia demissa. Mar Ecol Prog Ser 58:299-310

> Lehane C, Davenport J (2002) Ingestion of mesozooplankton by three species of bivalve: Mytilus edulis, Cerastoderma edule and Aequipecten opercularis. J Mar Biol Assoc UK 82:615-619

Li B, Ward JE, Holohan BA (2008) Transparent exopolymer particles (TEP) from marine suspension feeders enhance particle aggregation. Mar Ecol Prog Ser 357:67-77

> Menden-Deuer S, Lessard EJ (2000) Carbon to volume relationships for dinoflagellates, diatoms and other protist plankton. Limnol Oceanogr 45:569-579

Meredyth-Young JL (1983) World beating technology in Sounds. Catch 83(10):17-18

Møhlenberg F, Riisgård HU (1978) Efficiency of particle retention in 13 species of suspension feeding bivalves. Ophelia 17:239-246

Mons MN, Van Egmond HP, Speijers GJA (1998) Paralytic shellfish poisoning: a review. RIVM Report 388802005. National Institute for Public Health and the Environment (RIVM), Bilthoven

> Montagnes DJS, Berges DA, Harrison PA, Taylor FJR (1994) Estimating $\mathrm{C}$, nitrogen, protein and chlorophyll a from volume in marine phytoplankton. Limnol Oceanogr 39: 1044-1060 
Owen G (1974) Feeding and digestion in the Bivalvia. Adv Comp Physiol Biochem 5:1-35

Pile AJ, Young CM (1999) Plankton availability and retention efficiencies of cold-seep symbiotic mussels. Limnol Oceanogr 44:1833-1839

Ren JS, Ross AH, Hayden BJ (2006) Comparison of assimilation efficiency on diets of nine phytoplankton species of the greenshell mussel Perna canaliculus. J Shellfish Res 25:887-892

Riisgård HU (1988) Efficiency of particle retention and filtration rate in 6 species of northeast American bivalves. Mar Ecol Prog Ser 45:217-223

Riisgård HU (2001) On measurement of filtration rates in bivalves - the stony road to reliable data: review and interpretation. Mar Ecol Prog Ser 211:275-291

Riisgård HU, Randløv A (1981) Energy budgets, growth and filtration rates in Mytilus edulis at different algal concentrations. Mar Biol 61:227-234

Safi KA, Gibbs MM (2003) The importance of different size classes of phytoplankton in Beatrix Bay, Pelorus Sound and the potential implications for the aquaculture of the mussel Perna canaliculus. NZ J Mar Freshw Res 37: 267-272

Safi KA, Hall JA (1997) Factors influencing autotrophic and heterotrophic nanoflagellate abundance in five water masses surrounding New Zealand. NZ J Mar Freshw Res 31:51-60

Safi KA, Hewitt JE, Sonia T (2007) The effect of high inorganic seston loads on prey selection by the suspensionfeeding bivalve, Atrina zelandica. J Exp Mar Biol Ecol 344: $136-148$

Shimeta J, Jumars PA (1991) Physical mechanisms and rates of particle capture by suspension-feeders. Oceanogr Mar Biol Annu Rev 29:191-257

Shumway SE, Cucci TL, Newell RC, Yentsch CM (1985a) Particle selection, ingestion, and absorption in filter-feeding bivalves. J Exp Mar Biol Ecol 91:77-92

Shumway SE, Cucci TL, Gainey L, Yentsch CM (1985b) A preliminary study of the behavioral and physiological effects of Gonyaulax tamarensis on bivalve molluscs. In: Anderson DM, White AW, Baden DG (eds) Toxic dinoflagellates. Elsevier, New York, NY

Sieburth JM, Smetacek V, Lenz J (1978) Pelagic ecosystem structure: heterotrophic compartments of the plankton and their relationship to plankton size fractions. Limnol Oceanogr 23:1256-1263

Smaal AC, Prins TC (1993) The uptake of organic matter and the release of inorganic nutrients by bivalve suspension feeder beds. In: Dame RF (ed) Bivalve filter feeders in estuarine and coastal ecosystem processes. SpringerVerlag, Berlin

Sobral P, Widdows J (2000) Effects of increasing current velocity, turbidity and particle-size selection on the feeding activity and scope for growth of Ruditapes decussatus from Ria Formosa, southern Portugal. J Exp Mar Biol Ecol 245:111-125

Editorial responsibility: Hans Heinrich Janssen, Oldendorf/Luhe, Germany
Soletchnik P, Goulletquer P, Heral M, Razet D, Geairon P (1996) Evaluation du bilan energetique de l'huitre creuse, Crassostrea gigas, en baie de Marenned-Oleron (France). Aquat Living Resour 9:65-73

- Tomaru Y, Udaka N, Kawabata Z, Nakano S (2002) Seasonal change of seston size distribution and phytoplankton composition in bivalve pearl oyster Pinctada fucata martensii culture farm. Hydrobiologia 481:181-185

Tomas CR (ed) (1997) Identifying marine phytoplankton. Academic Press, San Diego, CA

Urrutia MB, Iglesias JIP, Navarro E, Prou J (1996) Feeding and absorption in Cerastoderma edule under environmental conditions in the bay of Marennes-Oleron (W. France). J Mar Biol Assoc UK 76:431-450

Viherluoto M, Viitasalo M (2001) Temporal variability in functional responses and prey selectivity of the pelagic mysid, Mysis mixta, in natural prey assemblages. Mar Biol 138: 575-583

Von Elert E, Stampfl P (2000) Food quality for Eudiaptomus gracilis: the importance of particular highly unsaturated fatty acids. Freshw Biol 45:189-200

> Ward JE (1996) Biodynamics of suspension-feeding in adult bivalve molluscs: particle capture, processing, and fate. Invertebr Biol 115:218-231

Ward JE, Shumway SE (2004) Separating the grain from the chaff: particle selection in suspension- and deposit-feeding bivalves. J Exp Mar Biol Ecol 300:83-130

Ward JE, Macdonald BA, Thompson RJ, Beninger PG (1993) Mechanisms of suspension feeding in bivalves: resolution of current controversies by means of endoscopy. Limnol Oceanogr 38:265-272

> Ward JE, Newell RIE, Thompson RJ, MacDonald BA (1994) In vivo studies of suspension-feeding processes in the eastern oyster Crassostrea virginica (Gmelin). Biol Bull (Woods Hole) 186:221-240

Ward JE, Levinton JS, Shumway SE, Cucci T (1998) Particle sorting in bivalves: in vivo determination of the pallial organs of selection. Mar Biol 131:283-292

> Widdows J, Johnson D (1988) Physiological energetics of Mytilus edulis: scope for growth. Mar Ecol Prog Ser 46: 113-121

Widdows J, Fieth P, Worrall CM (1979) Relationships between seston, available food and feeding activity in the common mussel Mytilus edulis. Mar Biol 50:195-207

Winter JE (1978) A review on the knowledge of suspensionfeeding in lamellibranchiate bivalves, with special reference to artificial aquaculture systems. Aquaculture 13:1-33

> Wong WH, Levinton JF, Twining BS, Fisher NS (2003) Assimilation of micromesozooplankton by zebra mussels: a demonstration of the food web link between zooplankton and benthic suspension feeders. Limnol Oceanogr 48: 308-312

Zeldis J, Robinson K, Ross A, Hayden B (2004) First observations of predation by New Zealand greenshell mussels (Perna canaliculus) on zooplankton. J Exp Mar Biol Ecol 311:287-299

Submitted: June 11, 2009; Accepted: September 30, 2010 Proofs received from author(s): November 4, 2010 